\title{
LIFE WITHOUT LIMBS: TETRA-AMELIA
}

\section{Jeneeta Baa *1, R.K.Behera ${ }^{2}$.}

${ }^{*}$ Assistant Professor, Department of Anatomy, GVP Institute of healthcare and medical technology, Visakhapatnam, Andhra Pradesh, India.

${ }^{2}$ Tutor, Department of Anatomy, M.K.C.G.Medical College and Hospital, Berhampur, Odisha, India.

\section{ABSTRACT}

Amelia is defined as the complete absence of the skeletal parts of a limb. Tetra- amelia, is the absence of all the four limbs is a very rare condition with an incidence range of $1.5-4 / 100,000$ births. Many factors causing various limb defects are genetic, environmental (teratogens), vascular compromise by amniotic bands and conditions like oligohydraminos and maternal diabetes. Point mutation in the WNT gene plays a major role in causing limb defects.

KEY WORDS: Amelia, Tetra- amelia, Genetic, Teratogens, Maternal diabetes, Oligohydraminos.

Address for Correspondence: Dr. Jeneeta Baa, Assistant Professor, Department of Anatomy, GVP Institute of health care and medical technology, Visakhapatnam, Andhra Pradesh 530048, India.

E-Mail: drjeneetabaa@gmail.com

Access this Article online

Quick Response code

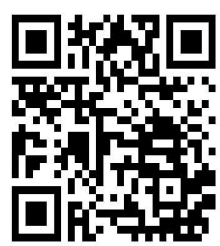

DOI: $10.16965 /$ ijar.2018.327

Journal Information

International Journal of Anatomy and Research

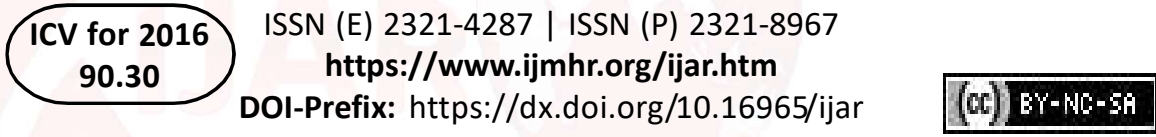

Article Information

Received: 17 Jul 2018

Peer Review: 18 Jul 2018

Revised: None
Accepted: 06 Sep 2018

Published (O): 10 Oct 2018

Published (P): 10 Oct 2018

\section{INTRODUCTION}

The most critical period of limb development is from 24 to 36 days after fertilization [1].Limb defects occur in approximately 6 per 10,000 live births. Exposure to teratogens before day 33 results in serious limb defects .It may include major defects like amelia(complete absence of limbs), meromelia (partial absence), phocomelia (rudimentary hands or seal limbs) and minor defects like macrodactyly (overgrowth), polydactyly (duplication) and micromelia (all the segments of the extremities are shorter).Factors causing various limb defects are genetic, environmental (teratogens), vascular compromise by amniotic bands and conditions like oligohydraminos and maternal diabetes.

\section{CASE REPORT}

A full term, dead female foetus was obtained at the department of anatomy, MKCG medical college, Berhampur from $\mathrm{CHC}$ Badagada of Ganjam district in Odisha. On examination the baby had absence of all the four limbs. She was born to a couple of non- consanguineous marriage. Mother was non-alcoholic and nondiabetic with no history of radiation exposure.

Findings: On external examination following was observed as shown in figure 1.

\section{Head \& Neck}

1.Cranium normal.

2.Face-Unilateral right upper cleft lip and cleft palate

3.Tongue ,Ear,Nose,Eyes -normally developed

Limbs:

4. Skeletal parts of the upper and lower limbsCompletely absent

\section{G.I.System}

5.Intact anterior and posterior abdominal wall. 
6. Rudimentory external genitalia, atresia of vagina.

7. Anus normally developed with presence of meconium.

Fig. 1: Baby with absence of upper and lower limbs(Tetraamelia) associated with cleft lip and cleft palate.

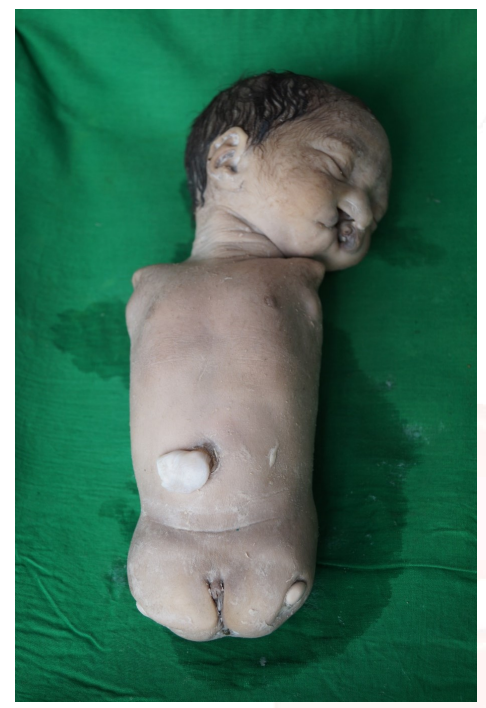

\section{DISCUSSION}

Cases of Amelia has been reported in the literature but there are very few cases of tertra-amelia recorded till date. We are presenting a case report of an dead infant with tetra-amelia i.e absence of all the four limbs. Smithells (1962) has reported several cases of tetra-amelia. Amelia with Robert syndrome has also been reported by Song et al [2]. Amelia is found to be transmitted in some Arabs and Turkish families in an autosomal recessive manner. The etiology of Amelia is thought to be sporadic, yet its genetic basis cannot be ruled out. Different modes of inheritance like autosomal recessive, $X$-linked dominant and autosomal dominant indicates the genetic heterogenicity of the condition [3].

Research in animals show that WNT gene is critical for limb outgrowth. Wingless type MMTV, which is a part of a large family of WNT genes plays a major role in development before birth. It determines the antero-posterior axis during the earliest embryonic stage. It also helps in normal formation of facial features, head, heart, lungs, neurons, skeletal and genitalia. Tetra-amelia syndrome is a health condition related to mutation in WNT3 gene. The gene is located in the 17q21.The mutation that occur in the WNT3 gene is the point mutation in a sequence of DNA that results in premature stop codon in the transcribed RNA. This mutation is referred as GIn83Ter and results in the production of abnormally non-functional version of the WNT3 protein [4]. Thus loss of the WNT3 protein disrupts normal limb formation before birth and leads to other serious birth defects associated with tetra-amelia syndrome.

In many cases, the lungs are under-developed which makes breathing difficult so that the babies are mostly stillborn or die shortly after birth [5].In our case also the twenty years old primigravida vaginally delivered the $2.1 \mathrm{~kg}$ baby, who cried soon after birth but died twenty minutes later. Recurrence of Amelia is also reported in some families but in our case family history was non-contributory. Even cases of tetra-amelia are reported with a normal chromosomal finding.

\section{CONCLUSION}

This case is reported because of its rare occurrence so that proper awareness can be spread. Due to absence of antenatal check-up diagnosis was made only after the baby was delivered. The parents were counselled for a low recurrence rate and were advised for antenatal check-up as well as early anomaly scan in future pregnancies. Antenatal screening, karyotyping analysis, and genetic counselling are recommended to reduce the risk of such congenital anomalies.

\section{Conflicts of Interests: None}

\section{REFERENCES}

[1]. Lenz W. Genetics and limb deficiencies. Clin Orthop Relat Res 1980;146:9-17.

[2]. Song SY, Chi JG. Tri-amelia and phocomelia with multiple malformations resembling Roberts syndrome in a fetus: Is it a variant or a new syndrome? Clin Genet 1996;50:502-4.

[3]. Morey MA, Higgens RR. Electro-amelia syndrome associated with an interstitial deletion of 7q.AmJ Med Genet 1990.Jan;35(1):95-9910.1002/ ajmg.1320350118[pubmed]

[4]. Niemann S, Zhao C, Pascu F, Stahl U, Aulepp U, Niswander L, et al. Homozygous WNT3 mutation causes tetra-amelia in a large consanguineous family. Am J Hum Genet 2004;74:558-63.

[5]. Basaran S, Yüksel A, Ermis H, Kuseyri F, Agan M, Yüksel-Apak M. Tetra-amelia, lung hypo-/aplasia, cleft lip-palate, and heart defect: A new syndrome? Am J Med Genet 1994;51:77-80.

How to cite this article: Jeneeta Baa, R.K.Behera. LIFE WITHOUT LIMBS: TETRA-AMELIA. Int J Anat Res 2018;6(4.1):5733-5734. DOI: 10.16965/ijar.2018.327 